Anna Warakomska

Warszawa

\title{
PROBLEMY MIĘDZYKULTUROWE W NIEMCZECH XXI WIEKU NA PRZYKŁADZIE DYSKUSJI O BUDOWIE MECZETU W KOLONII
}

Problem współistnienia różnorodnych kultur nie jest w Europie, również w Niemczech, zjawiskiem nowym ${ }^{1}$, czego egzemplifikacji dostarczają dzieje wielkich antagonizmów, ale jednak także koegzystencji, między Atenami i resztą „,barbarzyńskiego" świata, Atenami i Rzymem, Rzymem i Jerozolimą, Rzymem i Germanami, Rzymem i Bizancjum etc² .

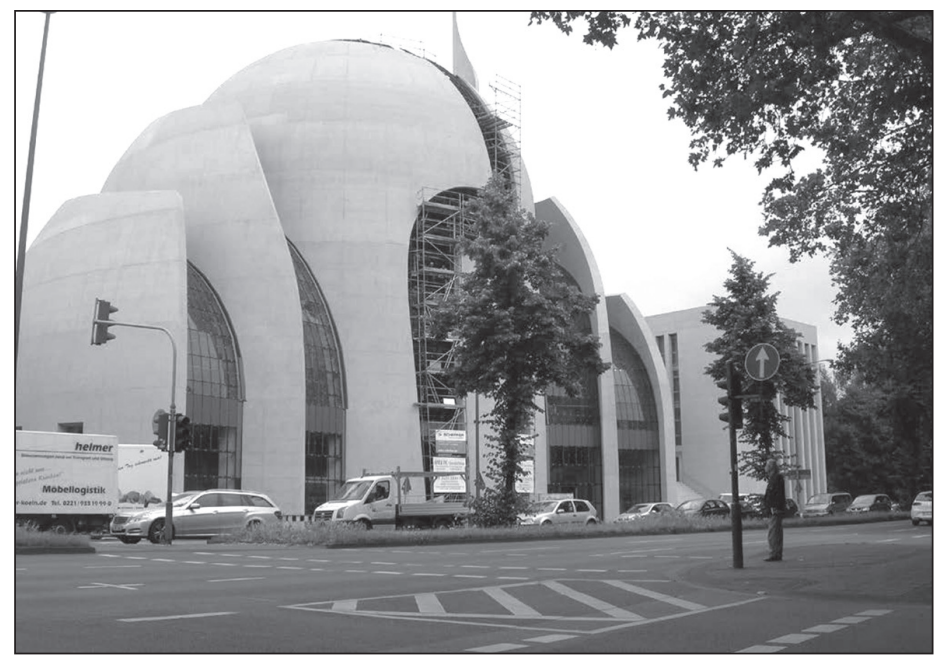

Fot. Budowa meczetu

${ }^{1}$ Szerzej na ten temat zob. Peter Rietbergen, Europa. Dzieje kultury. Z angielskiego przełożył Robert Bartołd, Warszawa 2001, s. 19-91 oraz 114-130.

${ }^{2}$ Por. ibidem, s. 95-167. 
I nawet jeśli od średniowiecza czy późnego antyku na kontynencie dominowała cywilizacja chrześcijańska, to w wielu jego częściach obecne były formacje zorientowane odmiennie od właśnie tej dominującej³

Za dobry przykład posłużyć może w tym kontekście, jakkolwiek cechujące się znaczną niewspółmiernością, to jednak współistnienie, dwóch kultur opartych na podłożu wielkich religii Pisma: judaizmu i chrześcijaństwa. Martin Goodman w swoim doniosłym dziele o zderzeniu antycznych cywilizacji Rzym i Jerozolima pisał o tym fakcie m.in.: „Istniało wiele powodów, by chrześcijanie zawłaszczyli sobie tożsamość Izraela. Najważniejszym była rola Pisma Świętego w ich myśli i obrządku. Chrześcijanie wiedzieli, że Stary Testament, zbiór uświęconych tekstów, które stanowiły fundament chrześcijańskiej wiary, należał pierwotnie do Żydów. Teksty pism świętych znajdowały się w synagogach, gdzie regularnie czytano je wiernym na głos i omawiano. W II wieku większość dostępnych egzemplarzy tych tekstów była dziełem żydowskich kopistów. Interpretacje (ogromnej większości) wersetów Pisma Świętego, w których chrześcijanie nie doszukali się jeszcze chrystologicznych odniesień, pochodziły niemal wyłącznie z długiej tradycji żydowskiej egzegezy. Nawet w kwestii brzmienia tekstu chrześcijanie musieli polegać na Septuagincie, greckim przekładzie ksiąg biblijnych sporządzonym, o czym wszyscy wiedzieli, przez żydowskich tłumaczy. Zarówno Żydzi, jak i poganie uważali, że żydowskie księgi święte autorytatywnie określają odwieczne obyczaje Żydów, takie jak przestrzeganie szabatu, obrzezanie czy przepisy żywieniowe. Teksty te łączyły Żydów i chrześcijan, a zarazem odróżniały ich od pogan"4. Fragment ten najlepiej chyba oddaje naturę motywów tolerowania przez chrześcijan ich starszych braci w wierze na przestrzeni dziejów w różnych zakątkach Europy.

Na marginesie warto zaznaczyć, iż owa tolerancja nie zawsze oznaczała ład i pokojowe współdziałanie, o czym poucza historia, jak też w wielu miejscach, m.in. w Epilogu Geneza antysemityzmu ${ }^{5}$ książka Goodmana. Należy się zgodzić z jej autorem, iż „przez niemal dwa tysiące lat, do roku 1948, chrześcijanie nie dopuszczali do siebie myśli o odrodzeniu się żydowskiego państwa"', zauważyć jednak trzeba jednocześnie, że judaizm i, co się z tym wiąże, kultura Żydów w Europie od czasów chrystianizacji jako jedna z nielicznych przetrwała, inne - uznane za pogańskie równie skutecznie, co brutalnie wypleniono.

\footnotetext{
${ }^{3}$ Por. Krzysztof Pomian, Europa i jej ludy, Gdańsk 2009, s. 17-71.

${ }^{4}$ Martin Goodman, Rzym i Jerozolima. Zderzenie antycznych cywilizacji. Przekład Olga Zienkiewicz, Warszawa 2007, s. 388-389.

${ }^{5}$ Por. ibidem, s. 424-429.

${ }^{6}$ Ibidem, s. 428.
} 
Także trzecia wielka religia Pisma - islam oraz wyrosła na jej gruncie kultura cieszyły się w Europie odmiennymi kolejami losu, od intelektualnej wymiany datującej się na czasy Awicenny i Awerroesa, myślicieli zainspirowanych starożytną filozofią grecką i hellenistyczną, oraz jej wpływu na teologię muzułmańską, po ukształtowanie się $\mathrm{w}$ drugiej połowie XX wieku muzułmańskiego fundamentalizmu ${ }^{7}$. Wśród doniosłych zdarzeń dotyczących cyrkulacji obu wymienionych kultur wymienić należy i w literaturze przedmiotu często się wymienia ${ }^{8}$ obecność islamu na Półwyspie Iberyjskim.

Wielu badaczy zagadnienia przychyla się do tezy o znacznym wzbogaceniu europejskiego renesansu i, co się z tym wiąże, korzystniejszym rozwoju nowożytnej kultury europejskiej dzięki muzułmańskim wpływom. Janusz Danecki, podkreślając znaczenie islamu dla tej kultury, pisze: „Bardzo trudno jest opisać kulturę, która z jednej strony ma wspólne korzenie z naszymi religiami, z drugiej jednak tworzy zupełnie inne uniwersum wiary i tradycji. Tak jest z islamem. Mamy z nim wspólne korzenie, ba, dziedzictwo islamu w znacznej mierze zdecydowało o kształcie cywilizacji europejskiej" ${ }^{\prime 9}$. Natomiast Konrad Pędziwiatr notuje na ten temat m.in.: „Prawie dziewięciusetletniej obecności muzułmanów na Półwyspie nie sposób jednak nie zauważyć szczególnie w takich miejscach, jak Granada czy Kordoba. Muzułmanie stworzyli na Półwyspie Iberyjskim niezwykle bogatą kulturę, która promieniowała na całą współczesną Europę. Nie tylko przechowali wiedzę starożytnej Grecji, ale twórczo ją rozwinęli i w ten sposób w znacznym stopniu przyczynili się do rozwoju nowoczesnej nauki filozofii w wiekach późniejszych"10. I powołując się na źródła fachowe, konkluduje: „Gdyby nie spuścizna muzułmańskiej Hiszpanii, to europejski renesans, nigdy nie byłby tak imponujący i nie przyjąłby tak wszechstronnego charakteru (Watt, 1972, Jayyousi 1994, Danecki 1998). Stąd niektórzy autorzy sugerują, by patrzeć na islam jako trzeci (obok judeochrześcijańskiego i grecko-rzymskiego) filar kultury europejskiej (Garaudy 1984, Lathion 2001)"11.

Zapewne przekonanie o wpływie i ewentualnie dobrodziejstwach kultury muzułmanów względem cywilizacyjnego dziedzictwa Europejczyków niewiele ma wspólnego z nowoczesną debatą polityczną, jaka

7 Por. Islam, [w:] Religie świata, Encyklopedia PWN, wierzenia, bogowie i święte księgi, Warszawa 2008, s. 382-389.

${ }^{8}$ Por. J. Danecki, Co zawdzięczamy islamowi, [w:] „Znak” 1/1998, s. 37-47.

9 Janusz Danecki, Podstawowe wiadomości o islamie. Warszawa 2007, s. 8.

${ }_{10}$ Konrad Pędziwiatr, Od islamu imigrantów do islamu obywateli: muzulmanie w krajach Europy Zachodniej, Kraków 2007, s. 23.

11 Ibidem. 
toczy się głównie na Zachodzie Europy w związku z tzw. zderzeniem cywilizacji12 i której nowe odsłony towarzyszą wszelkim kontrowersyjnym na Zachodzie fenomenom, od dyskusji o prawie do noszenia chust w miejscach publicznych przez muzułmanki, przez godne potępienia akty terroru islamistycznych fundamentalistów, po najnowszy w Niemczech spór o uznanie obrzezania nieletnich za nieuprawnione uszkodzenie ciała. Niegdysiejsze przenikanie się kultur w Europie nie wydaje się też istotnie wpływać na charakter współczesnych problemów społecznych na kontynencie między większością obywateli a muzułmańską mniejszością. Warto jednak o nim pamiętać, gdyż może posłużyć za przykład ilustrujący owocną koegzystencję.

Jako inna ważka sprawa, również związana z zamierzchłą historią, jawią się w tym kontekście religia oraz różnice kulturowe o charakterze doktrynalnym. Dlatego też warto w tym miejscu poświęcić kilka uwag owej kwestii. Według Encyklopedii PWN cechą charakterystyczną islamu jest: ,jego wszechobejmujący charakter, a przez to ścisłe powiązanie kwestii religijnych i świeckich. Islam reguluje życie indywidualne i społeczne muzułmanów tworzących wspólnotę w pełni podległą jednemu Bogu. Ponieważ człowiek jest winien Bogu absolutne posłuszeństwo, państwo i władzę uważa się za pochodzące od Boga. Stąd wywodzi się zasada absolutnego podporządkowania Bogu, wyrażona w muzułmańskim determinizmie i kontrowersjach na temat przeznaczenia człowieka (kadar)"13.

Jakkolwiek owe kulturowe uściślenia o podłożu teologicznym wydawać by się mogły we współczesnym zsekularyzowanym świecie Zachodu anachronizmem, nie należy ich bagatelizować. Stają się bowiem na powrót aktualne i, co ciekawe, rozpalają serca, a także umysły zwykłych obywateli coraz częściej uczestniczących w debatach politycznych i poszukujących źródeł społecznej dysharmonii właśnie w różnicach doktryn religijnych oraz powstałej na ich gruncie odmiennej tradycji kulturowej. Jedną z egzemplifikacji podobnego przeciwstawienia doktryn i tradycji wydaje się debata o budowie meczetu w Kolonii, podczas której wymienione czynniki poza wieloma innymi odegrały niemałą rolę.

Przed przystąpieniem do analizy rzeczonej debaty, warto zatrzymać się chwilę przy danych historycznych oraz statystycznych dotyczących obecności muzułmanów w Niemczech, danych w pewnym sensie obrazujących społeczną rangę problemu.

${ }^{12}$ Zob. Samuel Huntington, Zderzenie cywilizacji $i$ nowy kształt ładu światowego, Warszawa 1997; Günther Lachmann, Tödliche Toleranz. Die Muslime und unsere offene Gesellschaft. Mit einem Beitrag von Ayaan Hirsi Ali über die Situation der muslimischen Frauen, München/ Zürich 2007.

${ }^{13}$ Islam, op. cit., s. 385-386. 
Liczbowo znaczna obecność muzułmanów w Niemczech datuje się na okres ostatnich dziesięcioleci XX wieku po chwilę obecną, chociaż nie należy zapominać o historycznych początkach sprzed ponad trzystu lat ${ }^{14}$. Faruk Şen i Hayerettin Aydın, autorzy książki o islamie w Niemczech, podają, że pierwsi muzułmanie, tzw. „Beutetürken”, czyli niewolnicy zaliczani do "tureckiego łupu” pojawili się na terenach niemieckojęzycznych w XVII stuleciu w wyniku wojen między imperium osmańskim i mocarstwami Europy środkowej. Jednakże wolność religijną przyznano ludności muzułmańskiej dopiero po 1739 r. w Prusach. Za panowania Fryderyka II. muzułmanie zaczęli wchodzić w skład pruskiej armii, w 1798 r. w Berlinie pochowano osmańskiego dyplomatę, a w $1866 \mathrm{r}$. utworzono $\mathrm{w}$ tym mieście pierwszy muzułmański cmentarz, który wedle autorów publikacji pozostaje do dziś jedyną muzułmańską nekropolią na terenie Niemiec. Również pierwszy architektonicznie znaczący budynek meczetu powstał w stolicy Prus. W 1930 roku berlińskie Towarzystwo Niemiecko-Muzułmańskie powołało do życia imponującą budowlę z dwudziestosześciometrową kopułą oraz dwoma trzydziestodwumetrowymi minaretami, którą można podziwiać do dziśs ${ }^{15}$.

Wśród podanych informacji na uwagę zasługuje także fakt, że wymienione Towarzystwo podejmowało liczne inicjatywy mające na celu dialog międzykulturowy, m.in. przyjmowało w swoje szeregi również chrześcijan, a także organizowało liczne spotkania, w których do 1933 roku uczestniczyło wielu znanych obywateli, np. Tomasz Mann, Albert Einstein czy Hermann Hesse ${ }^{16}$.

Ale współczesna debata o różnicach między kulturami i związanych z tymi różnicami potencjalnych konfliktach nie dotyczy owej przedwojennej społeczności muzułmańskiej w Niemczech. Koncentruje się natomiast zdecydowanie na przedstawicielach tej społeczności (oraz ich przyzwyczajeniach i formach egzystencji) przybywających do Republiki Federalnej od lat pięćdziesiątych XX wieku po chwilę obecną, a także na ich potomkach.

W źródłach odnoszących się do zagadnienia podaje się różne daty początków zjawiska. Pędziwiatr twierdzi za Nielsenem, iż pierwsi tureccy pracownicy zaczęli napływać do Niemiec w wyniku podpisania umowy bilateralnej między Ministerstwem Pracy Landu Schlezwik-Holsztyn i Tureckim Ministerstwem Spraw Zagranicznych w 1957 roku, a właściwe fale migracyjne nastąpiły dopiero po 1961 roku, zwłaszcza od roku 1962, „,czyli czasu podpisania umowy między rządami Turcji i Niemiec o rekrutacji

\footnotetext{
${ }^{14}$ Faruk Şen, Hayerettin Aydın, Islam in Deutschland, München 2002, s. 10.

15 Ibidem, s. 12.

16 Por. ibidem.
} 
pracowników"17. Źródła niemieckie korygują nieco te dane. Lachmann za datę rozstrzygającą dla dalszej historii podaje datę 31. października 1961, kiedy to podpisano „das [...] Abkommen zur Anwerbung türkischer Arbeitskräfte für den deutschen Arbeitsmarkt”18 („umowę o pozyskiwaniu tureckiej siły roboczej dla niemieckiego rynku pracy"). Przy okazji Lachmann przypomina o innym znamiennym w skutki akcie prawnym z tamtego czasu, mianowicie o podpisanej w 1963 roku przez EG (Europäische Gemeinschaft = Wspólnotę Europejską) i Turcję umowie o wolnym przemieszczaniu się, na mocy której pracownicy z Turcji zrównani zostali w prawach z innymi pracownikami z państw Wspólnoty. Fakt ten spowodował wedle Lachmanna nieporównywalną z innymi falę imigracji oraz długodystansowo poważną zmianę wizerunku wielu niemieckich miast ${ }^{19}$. Natomiast Faruk Şen i Hayerettin Aydın obok znowu nieco odbiegających od poprzednio podanych dat (np. „umowa z Turcją z roku 1963” $)^{20}$ usiłują zwrócić uwagę na jeszcze jedną istotną kwestię, mianowicie różne tożsamości narodowe wyznawców islamu w Niemczech ${ }^{21}$. Piszą o tym m.in.: „Eine Zuwanderung von Muslimen in größerer Zahl begann erst nach der Unterzeichnung von Anwerbeabkommen mit Staaten, die entweder eine muslimische Bevölkerungsmehrheit hatten wie z.B. Türkei, Marokko und Tunesien oder einen beträchtlichen muslimischen Anteil stellten, wie z.B. das ehemalige Jugoslawien"22.

Pomijając nieścisłości informacyjne oraz różnorodne akcentowanie danych, w pracach dotyczących tematu ważne wydają się dwie konkluzje podzielane przez większość badaczy, a więc zgoda, co do powodów współczesnego pojawienia się muzułmanów w Niemczech oraz zbieżne poglądy dotyczące ocen ówczesnych politycznych zaniechań. Panuje zatem jednomyślność w kwestii wielkiej potrzeby uzupełnienia niedoborów na błyskawicznie rozwijającym się niemieckim rynku pracy w latach 60 . XX wieku oraz w sprawie kompletnego nieprzygotowania obydwu zainteresowanych stron, jeśli chodzi o potencjalne różnice czy problemy na tle

${ }^{17}$ Por. Konrad Pędziwiatr, Od islamu..., op. cit., s. 64.

18 Por. Günther Lachmann, Tödliche Toleranz..., op. cit., s. 18.

19 Ibidem.

${ }^{20}$ Faruk Şen, Hayerettin Aydın, Islam in Deutschland, op. cit., s. 12.

${ }^{21}$ Wypada tu jednocześnie wspomnieć, że inne źródła datują rzeczoną umowę na 30.10.1961 r. Zob. www.de.wikipedia.org/wiki/Anwerbeabkommen_zwischen_der_Bundesrepublik_Deutschland_und_der_Türkei, stan 23.10.2012.

${ }^{22}$ Faruk Şen, Hayerettin Aydın, Islam in Deutschland, op. cit., s. 12. [„Imigracja muzułmanów na szerszą skalę rozpoczęła się dopiero po podpisaniu umów o rekrutacji pracowników z krajami, których większość społeczeństwa była muzułmańska, jak np. Turcja, Maroko lub Tunezja, albo które dysponowały znacznym odsetkiem muzułmanów, jak np. była Jugosławia", tłum. A.W.]. 
kulturowym ${ }^{23}$. W istocie niemiecka gospodarka lat powojennej odbudowy i następującego po niej rozwoju potrzebowała siły roboczej (również do wykonywania czynności niechętnie podejmowanych przez ludność rdzennie niemiecką), a ponieważ nie zakładano trwałego pozostania "gastarbeiterów" w Niemczech, nie troszczono się też przesadnie o położenie czy duchowe potrzeby przybyłych pracowników. Podsumowująco i chyba najtrafniej przedstawił sprawę Lachmann, twierdząc: „Zunächst machten sich überdurchschnittlich gebildete Männer mit qualifizierten Berufsaubildungen auf den Weg nach Deutschland. Später waren es hauptsächlich Menschen aus dem Osten der Türkei, aus den verarmten Regionen Anatoliens. Sie besaßen zumeist keine brauchbare Berufsausbildung. Niemand hatte die Türken, aber auch Portugiesen, Spanier und Griechen auf das vorbereitet, was sie in der boomenden Bundesrepublik erwartete. Und die Bundesrepublik war auf sie nicht vorbereitet. Diejenigen, die sie für gering qualifizierte Beschäftigungen nach Deutschland geholt hatten, sahen in den Gastarbeitern nichts weiter als eine Kalkulationsgröße in einer nüchternen Kosten-Nutzen-Rechnung"24.

Dopiero w późniejszym czasie, a więc od lat siedemdziesiątych XX wieku wraz z następującym łączeniem rodzin wskutek tzw. „Anwerbestopp" (1973), czyli zarządzenia regulującego dalszą imigrację zarobkową do Niemiec, w kraju pojawiły się liczniej także rodziny zatrudnionych pracowników ${ }^{25}$. Obecność żon i dzieci zmieniła nie tylko ich prywatną sytuację życiową ale także zewnętrzny obraz imigrantów w przestrzeni publicznej. W wielu niemieckich miastach zaczęły powstawać prawdziwe skupiska ludności muzułmańskiej, które wyróżniała nie tylko powierzchowność, a więc rysy, wygląd i odmienny sposób ubrania. Swoją społeczną obecność ludność ta coraz częściej zaznaczała także dzięki tworzeniu punktów usługowych, sklepików, restauracji, kafejek oraz miejsc modlitw. W szkołach zwiększał się stopniowo odsetek dzieci z poza-niemieckimi korzeniami. Młode kobiety w hidżabach wyraźnie różniły się od swoich

${ }^{23}$ Por. Günther Lachmann, Tödliche Toleranz..., op. cit., s. 18; Faruk Şen, Hayerettin Aydın, Islam in Deutschland, op. cit., s. 12-15; Konrad Pędziwiatr, Od islamu..., op. cit., s. 64-65; Thilo Sarrazin, Deutschland schafft sich ab. Wie wir unser Land aufs Spiel setzen, München 2012, s. 58.

${ }^{24}$ Günther Lachmann, Tödliche Toleranz..., op. cit., s. 18. [„Najpierw w drogę do Niemiec udali się ponadprzeciętnie wykształceni mężczyźni o wysokich kwalifikacjach zawodowych. Później byli to przede wszystkim ludzie ze wschodu Turcji, ze zubożałych rejonów Anatolii. Zazwyczaj nie posiadali żadnego przydatnego wykształcenia zawodowego. Nikt nie przygotował Turków, ale też Portugalczyków, Hiszpanów i Greków na to, co czekało ich w prężnie rozwijającej się Republice Federalnej. A i Republika Federalna nie była na nich przygotowana. Ci, którzy przywiedli ich do Niemiec jako siłę do wykonywania mało wymagających zadań, widzieli w gastarbeiterach nic więcej ponad wielkość kalkulacyjną w trzeźwym rachunku zysków i strat", tłum A.W.].

25 Szerzej na ten temat zob. ibidem, s. 23 i n. 
niemieckich rówieśniczek. Muzułmanie stawali się obecni i widoczni na ulicach niemieckich miast.

$\mathrm{W}$ momencie zainicjowania budowy meczetu w Kolonii byli zatem społecznością dobrze znaną i mniej lub bardziej akceptowaną. Jednak bezpośrednio przed budową rozpoczętą w 2008 roku (07.11.2008 wydano urzędowe pozwolenie na zainicjowanie $\operatorname{prac}^{26}$ ) oraz $\mathrm{w}$ jej trakcie rozgorzała dyskusja nie tylko o samym meczecie, ale także o problemach „nieudanej integracji" ${ }^{27}$. Na wstępie podnoszono argumenty techniczno-formalne.

Głównym punktem spornym odnośnie do planów architektonicznych stała się obawa przed powstaniem w sercu dzielnicy Ehrenfeld przy jednej z głównych arterii komunikacyjnych Kolonii u zbiegu ulic Venloerstr. i Innere Kanalstr. obiektu o nazbyt dużych rozmiarach. Jego rozmach miał, zdaniem przeciwników projektu, przyćmić znaczenie katedry kolońskiej - okrzepłego symbolu miasta ${ }^{28}$.

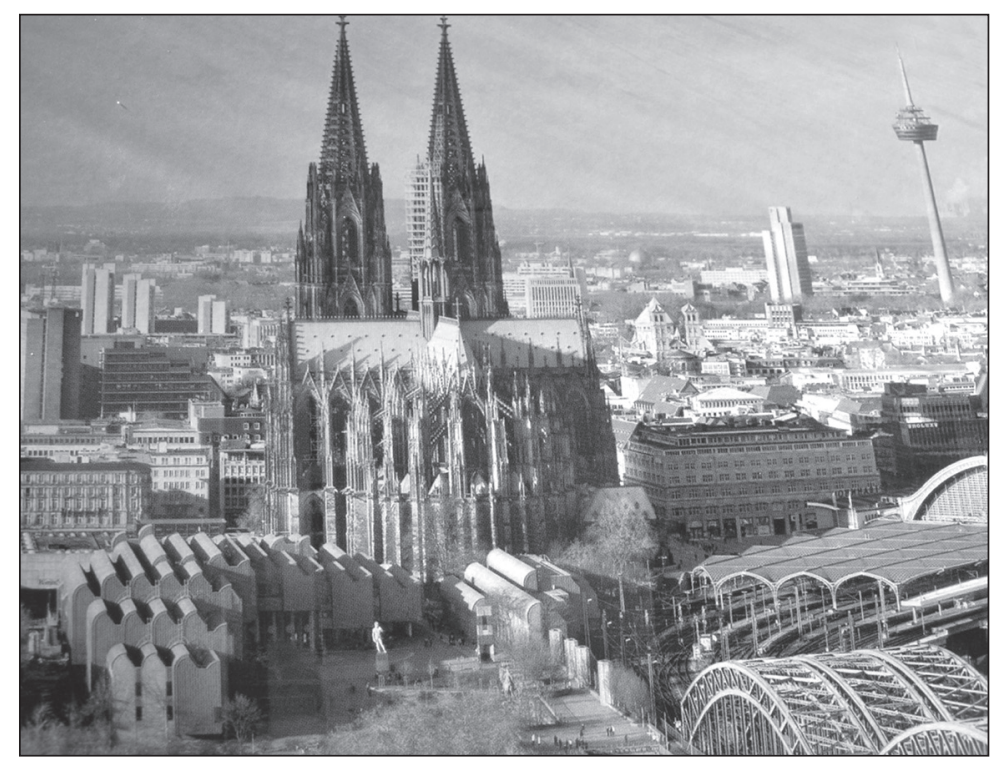

Fot. 2. Meczet pod katedrą kolońską

${ }^{26}$ Die DITIB Zentralmoschee Köln, http://de.wikipedia.org/wiki/DITIB-Zentralmoschee_K\%C3\%B6ln\#cite_ref-2, stan 23.10.2012.

27 Por. P.S. „Moscheebau ein falsches Zeichen”. Islam-Kritik, FAZ vom 23.05.2007, http:// www.faz.net/aktuell/politik/islam-kritik-moscheebau-ein-falsches-zeichen-1436284.html, stan z 3.10.2012; Günther Lachmann, Tödliche Toleranz, op. cit., s. 54-59.

${ }^{28}$ Por. Piotr Jendroszczyk: Wojna o islam w Kolonii, „Rzeczpospolita” z 20.09.2008 www.rp.pl/artyku193542.html. stan 03.10.2012. 
Mógł też w razie realizacji przyczynić się do chaosu komunikacyjnego (zbyt licznie odwiedzający meczet wierni stanowiliby potencjalne zagrożenie dla ruchu i tak zakorkowanej już metropolii).

Kopuła budowli liczyła według planu 35 m wysokości, a towarzyszyć jej miały dwa minarety po $55 \mathrm{~m}$ każdy. W 2007 r. niemiecki architekt Paul Böhm oraz zleceniodawca projektu: Turecko-Islamska Unia ds. Religijnych (DITIB) odrzucili pomysł zmniejszenia minaretów, uzasadniając własne plany potrzebami estetycznymi, m.in. zachowaniem proporcji w stosunku do pozostałych otaczających budynków ${ }^{29}$. Niemałą rolę odegrały zapewne także prestiż i ranga świątyni ${ }^{30}$, która ma się stać centralnym obiektem kultu dla ponad 120 tys. mieszkańców Kolonii pochodzenia tureckiego oraz muzułmanów, przybyszów również z innych poza Turcją krajów, których liczbę w Nadrenii szacuje się łącznie z turecką większością na około 1,1 miliona obywateli, a w całych Niemczech nawet na około 3 miliony $^{31}$. Dlatego meczet będzie miał, a w właściwie już ma, $6.500 \mathrm{~m}^{2}$ powierzchni. Znajdują się tu oprócz 2.500 miejsc modlitwy pomieszczenia biblioteczne, szkoleniowe, seminaryjne, a także przeznaczone na działalność usługową i podziemny garaż $\dot{ }^{32}$. Propagatorzy budowy, powołując się na niemiecką konstytucję, przyznającą obywatelom wolność wyznania oraz prawo do godnego wypełniania kultu, mieli zatem pełne podstawy, aby domagać się powstania odpowiedniej do potrzeb świątyni.

Jej przeciwnicy nie powołują się jednak w swym proteście wyłącznie na argument zaburzenia ładu estetycznego czy symbolicznego w mieście. Ich obawy dotyczą też głębiej ukrytych lęków o podłożu kulturowym.

Najważniejszym w tym kontekście argumentem wydaje się twierdzenie, iż meczet stanie się fałszywym znakiem integracji, rozpowszechniane przez powstałe w 1996 roku stowarzyszenie Pro Köln. Jest to organizacja obserwowana przez niemieckie służby porządkowe, m.in. Urząd Ochrony Konstytucji, i uznana przez nie za związek ekstremalnie prawicowy oraz wrogo nastawiony do ustawy zasadniczej ${ }^{33}$. Media niemieckie uważają ją za

${ }^{29}$ Die DITIB Zentralmoschee Köln, op. cit.

${ }^{30}$ W 2002 roku podczas wstępnych rozmów o budowie meczetu miasto zaproponowało inwestorom lokalizację w dzielnicy peryferyjnej Chorweiler. Odpowiedź sekretarza generalnego Centralnej Rady Muzułmanów w Niemczech, Axela Köhlera (FDP), cytuje jedna z kolońskich gazet: "Chorweiler ist nicht der Platz, den wir uns für eine zentrale repräsentative Moschee vorstellen", [„Chorweiler nie jest miejscem, które wyobrażamy sobie jako właściwe dla centralnego reprezentatywnego meczetu”]. Por. Helmut Frangenberg, Moschee möglichst in der City. Islamische Organisationen müssen sich auf Träger einigen. Cyt. za: „Kölnische Rundschau. Pressespiegel”, http://www.fdp-koeln.de/index. php?11=9\&12=0\&13=1\&aid=684, stan z 3.10.2012.

${ }^{31}$ Faruk Şen, Hayerettin Aydın, Islam in Deutschland, München 2002, s. 15.

${ }^{32}$ Die DITIB Zentralmoschee Köln, op. cit.

${ }^{33}$ Por. http://de.wikipedia.org/wiki/B\%C3\%BCrgerbewegung_pro_K\%C3\%B6ln, stan 23.10.2012. 
populistyczną, ksenofobiczną i rasistowską ${ }^{34}$, jednak jej przedstawiciele zasiadają w kolońskim ratuszu, tworząc kilkuosobową frakcję w Radzie Miasta.

We wrześniu 2008 roku Pro Köln usiłowała zorganizować konferencję reprezentantów ekstremalnej prawicy z krajów europejskich, mających jednocześnie demonstrować przeciw islamizacji Europy. Nie przypadkiem za miejsce spotkania wybrała właśnie Kolonię. To tu ma powstać największy meczet w Niemczech oraz jeden z większych w Europie. Markus Wiener, wiceprzewodniczący tej organizacji, odpierając zarzuty rasizmu miał wówczas oznajmić: "Chcemy jedynie uwidocznić zagrożenie, jakie niesie uległość wobec ekspansji islamu. W końcu trzeba powiedzieć nie"35. Upatrując zagrożenia dla Europy i cywilizacji Zachodu w islamie, zwolennicy tego typu myślenia uznają pomysł budowania meczetów na naszym kontynencie za chybiony ${ }^{36}$.

Znamienna w tym przypadku jest postawa Ralpha Giordano, publicysty i autora $\mathrm{z}$ Niemiec $\mathrm{z}$ osobistymi doświadczeniami Holocaustu, który od sympatyzowania z lub przynależności do Pro Köln zdecydowanie się dystansuje $^{37}$. Twierdzi jednak, że przyznając muzułmanom prawo do ekspresji ich obecności w tak widoczny sposób jak przez budowę świątyń, sugeruje się udaną integrację tej społeczności, a więc także uznanie jej praw w społeczeństwach demokratycznych. Tymczasem Giordano utrzymuje, że integracja taka nie nastąpiła i, co więcej, wyraża obawy, że nie uda się także w przyszłości: „Problemem nie są - według Giordano - meczety, lecz islam"38. Podobny pogląd o niereformowalnym anachronizmie już przed laty prezentowała Oriana Fallaci. W książce zatytułowanej „Wściekłość i duma" słynna dziennikarka udowadnia, że nie istnieje żaden umiarkowany islam, a elity polityczne Europy tolerują ekspansję tej religii w imię fałszywie pojętych wartości ${ }^{39}$.

Wartości kultury judeochrześcijańskiej, o których wspomina Fallaci, nie podzielają, również zdaniem Giordano, wyznawcy islamu, a nawet

${ }^{34}$ Por. Piotr Jendroszczyk, Zwyciężyli obrońcy islamu, „Rzeczpospolita”, 20.09.2008 www.rp.pl/artykul93446.html stan 03.10.2012.

${ }^{35}$ Ibidem.

${ }^{36}$ Por. ibidem: „W budowie lub w stadium planowania są teraz 184 muzułmańskie świątynie z kopułami i minaretami. Do tego dochodzi 2600 tzw. meczetów podwórkowych, w odnowionych halach fabrycznych czy salach gimnastycznych. Liczba muzułmanów w Niemczech sięga już 3,4 miliona, w zdecydowanej większości są pochodzenia tureckiego. Nowe świątynie powstają we Frankfurcie nad Menem, w Berlinie, Monachium i innych wielkich miastach".

37 Por. P.S., "Moscheebau ein falsches Zeichen”. Islam-Kritik, vom 23.05.2007, http:// www.faz.net/aktuell/politik/islam-kritik-moscheebau-ein-falsches-zeichen-1436284.html, stan z 3.10.2012.

${ }^{38}$ Por. Piotr Jendroszczyk: Zwyciężyli obrońcy islamu, op. cit.

39 Piotr Jendroszczyk: Wojna o islam w Kolonii, Rzeczpospolita 20.09.2008, www. rp.pl/ artyku193542.html. stan 03.10.2012. 
więcej, korzystając z tolerancji zachodnich demokracji, hołdują odmiennemu systemowi i propagują go. Natomiast system ów, jak utrzymuje autor, stoi w sprzeczności z niemiecką konstytucją ${ }^{40}$. Jako elementy najgroźniejsze dla kultury Zachodu Giordano wymienia tu podporządkowanie życia wiernych "totalitarnym poglądom na świat i religię" oraz brak równouprawnienia płci ${ }^{41}$. W kontekście tej krytyki często pojawia się też argument przymusowych małżeństw oraz ewentualnych mordów w akcie zemsty, także na niewiernych kobietach ${ }^{42}$. Wielce istotnym zarzutem wydaje się również ograniczanie wolności słowa i zrównywanie krytyki ze zniesławieniem. W jednym $\mathrm{z}$ artykułów w internetowej wersji FAZ publicysta podkreśla m.in.:

Ich werde meine Ansicht von Meinungsfreiheit auch nicht einem Ungeist anpassen, der sie so auslegt: „Alle haben das Recht, ihre Meinung frei auf eine Weise auszudrücken, die der Scharia nicht zuwiderläuft." Nein und dreimal nein! Die Scharia, das Gesetz des Islam, ist notorisch grundgesetzwidrig, ein skandalöser Anachronismus, das Fossil einer überholten Menschheitsepoche und ein schweres Hindernis auf dem Weg zur Reformierung und Modernisierung des Islam. Sie wird von mir genauso selbstverständlich in die kritische Methode einbezogen wie der Koran, die Biographie Mohammeds und das Alte und das Neue Testament. Und ich will das sagen, schreiben, denken dürfen - offizielle Fatwa-Drohung hin, inoffizielle her ${ }^{43}$.

Mówiąc o groźbie Fatwy, autor nawiązuje do pogróżek, jakie podobno po publicznym wyrażeniu swoich poglądów otrzymał w języku tureckim od nieznanych sprawców. Jego wypowiedzi są bardzo emocjonalne i niekiedy niezręczne, żeby nie powiedzieć niestosowne, np. kiedy przyrównuje kobiety w czadorach do „ludzkich pingwinów"44. Niemniej obawy,

${ }^{40}$ Ralp Giordano, Nein und dreimal nein!, http://www.faz.net/aktuell/politik/inland/ ralph-giordano-nein-und-dreimal-nein-1436280.html, stan 3.10.2012.

${ }^{41}$ Ibidem.

${ }^{42}$ Christian Geyer, Weg mit der Burka! Ralph Giordanos Vergleich, vom 25.05.2007, http://www.faz.net/aktuell/feuilleton/debatten/ralph-giordanos-vergleich-weg-mit-derburka-1437381.html.

${ }^{43}$ Ralp Giordano, Nein und dreimal nein!, op. cit. [„Nie dopasuje mojego przekonania o wolności słowa anachronizmowi, który owo przekonanie interpretuje następująco: ,Wszyscy mają wolne prawo wyrażać swoje poglądy, jednak w taki sposób, który nie stoi w sprzeczności z szariatem'. Nie i po trzykroć nie! Szariat, prawo islamu, jest notorycznie sprzeczne z konstytucją, skandalicznym anachronizmem, skamieliną minionej epoki ludzkości i dużą przeszkodą na drodze reformowania oraz modernizacji islamu. Będzie przeze mnie oczywiście tak samo poddawane metodzie krytycznej, jak Koran, biografia Mahometa, Stary i Nowy Testament. I chcę mieć prawo o tym mówić, pisać, myśleć - oficjalne groźby Fatwy z jednej, nieoficjalne z drugiej strony"].

${ }^{44}$ Por. P.S., "Moscheebau ein falsches Zeichen”. Islam-Kritik, vom 23.05.2007, http:// www.faz.net/aktuell/politik/islam-kritik-moscheebau-ein-falsches-zeichen-1436284.html, stan z 3.10.2012. 
które wyraża, często powracają w dyskusji medialnej i wydaje się, że nie mają szansy zniknąć, zważywszy choćby na dane statystyczne ilustrujące skalę imigracji z krajów muzułmańskich. Poza tym Giordano jako ofiara Holocaustu ma odwagę mówić głośno o rzeczach, o których być może inni tylko myślą ${ }^{45}$. W odniesieniu do, jego zdaniem, strachu polityków przed pomówieniem o nazizm i zbytniej uległości wobec mniejszości zauważa, iż przeważająca część niemieckiego społeczeństwa jest sceptycznie nastawiona do planu budowy meczetu i podkreśla: „Es ist erschreckend, dass sich viele Menschen nicht trauen, dies öffentlich zu zeigen, weil sie entweder Angst haben, in die rechtsextreme Ecke gestellt oder von Muslimen bedroht zu werden. Dies ist eine höchst gefährliche Situation"46.

Ale wypowiedź ta nie do końca znajduje potwierdzenie w statystykach. Według reprezentatywnej ankiety przeprowadzonej w czerwcu 2007 roku przez instytut badania opinii publicznej OmniQuest, a zainicjowanej przez „Kölner Stadt-Anzeiger”, okazało się, że tylko 31.4\% pytanych odrzucało pomysł budowy meczetu, natomiast $35,6 \%$ opowiadało się bez zastrzeżeń za jego powstaniem, a 27,1\% wyrażało poparcie w przypadku zredukowania planowanej wielkości obiektu ${ }^{47}$. Zwolennikami byli także poprzedni i obecny burmistrzowie Kolonii: Fritz Schramma (z CDU, pochodzący z Ehrenfeldu) i Jürgen Roters (SPD), jak też Josef Wirges (SPD), burmistrz dzielnicy Ehrenfeld, oraz znaczna część niemieckich mediów ${ }^{48}$. Co ciekawe, bardzo znany miejscowy proboszcz katolicki, Franz Maurer z parafii św. Theodora (Koln-Vingst) wezwał wiernych do kwesty na rzecz budowy meczetu, mówiąc: „Köln braucht diese Moschee” („Kolonia potrzebuje tego meczetu"), ponieważ wydobędzie „viele Muslime, die ja unsere Mitbürger sind... aus den Hinterhöfen”, („,wielu muzułmanów, którzy przecież są naszymi współobywatelami z zakamarków ${ }^{\prime \prime 49}$.

W 2010 roku budowla stanęła w podwójnym sensie słowa, tzn. meczet wyrósł z ziemi, widać jego zarysy, jednak od dwóch lat przesuwany jest termin jego ostatecznego otwarcia. W prasie pojawiły się spekulacje na temat opóźnień, mi. in. domysły o rzekomym przemyceniu elementów symboliki chrześcijańskiej do projektu lub zaostrzeniu kursu politycznego na jeszcze bardziej pro islamski w Turcji i potencjalne naciski z tej strony na

${ }^{45}$ Por. Berthold Kohler, Unter dem Brandeisen, „Frankfurter Allgemeine Zeitung”, nr 119 z 24.05.2007, s. 1.

${ }^{46}$ P.S., "Moscheebau ein falsches Zeichen”. Islam-Kritik, vom 23.05.2007, http://www. faz.net/aktuell/politik/islam-kritik-moscheebau-ein-falsches-zeichen-1436284.html, stan z 3.10.2012. [„To zastraszające, że wielu ludzi nie ma odwagi pokazać tego publicznie, ponieważ albo się boją zostać przypisani do ekstremalnej prawicy, albo zagrożenia ze strony muzułmanów. To jest wielce niebezpieczna sytuacja", tłum A.W.].

${ }^{47}$ Kölner gegen Moschee in geplanter Größe, „Kölner Stadt-Anzeiger”, 19. Juni 2007, s. 3.

48 Andreas Rossmann, Die Kölner Moschee. Der Film zum Bau, FAZ vom 09.07.2012 http://www.faz.net/-gsb-718m9, stan z 22.10.2012.

49 P.S., "Moscheebau ein falsches Zeichen", op. cit. 
zmianę architekta. Podczas oficjalnej konferencji prasowej przedstawicielka DITIB, czyli inwestora projektu, oznajmiła, że powodem przeniesienia terminu otwarcia meczetu są usterki techniczne zauważone w czasie prac i konieczność ich usunięcia przez nowego architekta ${ }^{50}$.

Jednak meczet jest już materialnie obecny, podobnie jak w przestrzeni publicznej Kolonii i Niemiec obecne są kwestie sporne związane z imigrantami pochodzenia tureckiego czy szerzej wyznawcami islamu. Pozostają nimi nieustannie:

1. Obawy przed zbyt szybkim postępem przyrostu naturalnego wśród zagranicznych przybyszów w relacji do rodzin rdzennie niemieckich

2. Zarzut nadużywania systemu społecznych zabezpieczeń

3. Zarzut odmienności mentalnej - mały nacisk rodzin na edukację

4. Kwestie szkół koranicznych i podejrzenie podżegania w nich do nienawiści

5. Nierówne i anachroniczne traktowanie kobiet

6. Tworzenie równoległych społeczeństw (poza odmiennymi obyczajami, odżywianiem, symboliką, strojem, ostatnio także równoległa jurysdykcja).

\section{Zusammenfassung}

Im vorliegenden Beitrag will die Autorin die aktuelle Diskussion zum Thema der interkulturellen Differenzen und ferner - der Islam in Europa am Beispiel der Auseinandersetzung um den Bau der Kölner Moschee erläutern. Von einem kurzen Rückblick auf die Geschichte der Anwesenheit der Türken in Deutschland sowie der Erinnerung an den partiell friedlichen Austausch zwischen den Kulturen ausgehend, expliziert sie die zeitgenössischen gesellschaftlichen Schwierigkeiten, die auf die religiösen wie auch sozialen Motive zurückzuführen sind und die die heutige deutsche Gesellschaft plagen. Am Ende des Textes werden die wichtigsten aufzählend zusammengestellt.

Die Autorin versucht ein möglichst objektives Bild der Auseinandersetzung zu präsentieren, indem sie einerseits die Befürworter des besagten Bauunternehmens zitiert, wie andrerseits ihre Gegner sprechen lässt. Zu belangreichsten Vertretern der Diskussion gehören hier u.a. die DITIB als Bauherrin sowie der Architekt Paul Böhm, die Politiker, Geistlichen und Publizisten, wie z.B.: Axel Köhler, Jürgen Roters, Josef Wirges, Franz Maurer, Ralph Giordano, Markus Wiener.

Es werden daher sowohl die verfassungsmäßigen Rechte und sonstigen Ansprüche der muslimischen Minderheit in Deutschland genannt, wie andererseits die Ängste oder gar Warnungen vor einer Unterwanderung durch eine fremde Kultur. Der Beitrag hat zum Ziel, dem polnischen Leser ein besseres Verständnis in diese brisante Problematik zu verschaffen.

${ }^{50}$ Die DITIB Zentralmoschee Köln, op. cit. 